\section{Photoscreening for refractive errors in children and young adults with severe learning disabilities using the MTI photoscreener}

\begin{abstract}
Purpose To test the potential ability of the MTI photoscreener to facilitate screening for significant refractive errors in children and young adults with severe learning disabilities. Methods Thirty-eight patients with severe learning disabilities from a special school were examined with the photoscreener, and underwent cycloplegic refraction, an ophthalmological and an orthoptic examination. The age at examination, the cause of learning disability, the pupil size, the number of photographs required for accurate interpretation, the co-operation of the subject and the presence or absence of strabismus were recorded. An educational psychologist had performed a psychological assessment on all the children. The results of the cycloplegic retinoscopy were compared with the photorefraction results.
\end{abstract}

Results A photorefraction was possible in 37 patients and cycloplegic refraction in all the patients. The patients had severe learning difficulties with an intelligence quotient of less than 50. All the patients had behavioural problems, 9 patients had associated cerebral palsy, 8 had chronic epilepsy, 1 patient was brain damaged from a non-accidental injury and 1 from a road traffic accident. The mean age of the patients was $10.0 \pm 4.9$ years (range 3-18 years), the average pupil diameter during photoscreening was $6.1 \pm 0.9 \mathrm{~mm}$ (range 4-8 $\mathrm{mm}$ ) and the average number of photographs required for each subject was $2.1 \pm 0.9$ (range 1-4). The photoscreener detected 10 patients with a manifest strabismus. There was one false positive and one false negative result giving a sensitivity of $\mathbf{9 2 . 8 \%}$ and a specificity of $\mathbf{9 0 \%}$.

Conclusion The examination of children with severe learning disabilities for refractive errors can be extremely difficult. The MTI photoscreener is an effective means of screening such children and young adults for refractive errors and strabismus so that the children with these abnormalities may be targeted for a more detailed evaluation.

Key words Photoscreener, Refractive errors, Severe learning disabilities

The incidence of refractive errors and strabismus is high in children with learning disabilities. ${ }^{1}$ Visual acuity is difficult to test; often the pupillary responses and the fixation behaviour are the only means of assessing these severely handicapped children. The clinical examination and evaluation with a cycloplegic refraction involves a considerable amount of time and patience to be accurate and is often inadequate. An additional problem is the altered behaviour of these children in an unfamiliar hospital environment. This places further constraints on the limited time available for each individual patient. However, it is this group of disadvantaged children who need help most, as their rehabilitation and care is helped by optimising their visual input. An accurate screening method whereby the children with significant visual problems are referred for further evaluation would allow more time for clinical evaluation of a targeted group with better utilisation of limited resources.

Photoscreening devices are effective tools for detecting refractive errors in children at risk of developing amblyopia; ${ }^{2}$ however, their role in evaluating refractive errors in children with severe learning disabilities (SLD) has not been assessed. We document our experience with the MTI photoscreener in a group of such children.

\section{Subjects and methods}

The parents or legal guardians of 40 children attending a school for those with special needs gave written informed consent for their

\author{
P. Watts \\ K. Walker \\ L. Beck \\ Cardiff Eye Unit \\ University Hospital of Wales \\ Cardiff CF4 4XW, UK
}

Patrick Watts, FRCOphth 58 Crystal Wood Road Heath

Cardiff CF4 4HW, UK

The authors have no financial or commercial interest in the photoscreener used in this study

Received: 30 October 1998 Accepted in revised form: 25 March 1999 


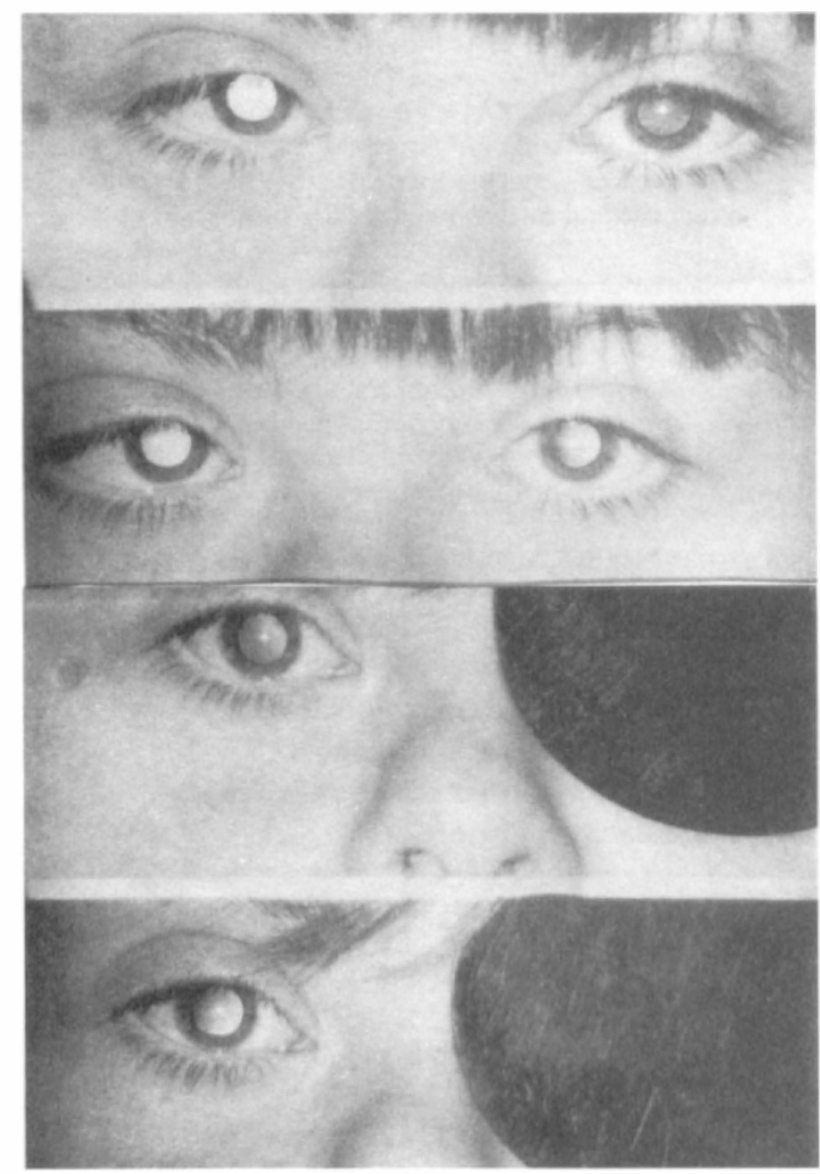

Fig. 1. Case 16. The upper two photographs demonstrate esotropia; hence only the left eye was used for interpretation (hypermetropic astigmatism). In the lower two photographs the esotropic right eye is now fixing with an occluder over the left eye, and hence can be used for interpretation.

children's eyes to be examined, which included refraction and photography. Two children's parents refused eye drops for the cycloplegic refraction and these patients were hence excluded from the analysis. Of the remaining 38 children, 22 were female and 16 male. The mean age of the patients was $10.0 \pm 4.9$ years (range $3-18$ years). All patients had been psychologically assessed and found to have severe learning disabilities and behavioural problems, and had an intelligence quotient (IQ) below 50. Nine patients had associated cerebral palsy, 8 patients had chronic epilepsy, 1 had sustained non-accidental injury and 1 had been in a road traffic accident, both in infancy. Communication skills were limited in all patients.

An orthoptist and an ophthalmologist examined all patients. The orthoptic assessment and the photoscreening results were masked to the examining ophthalmologist. The records of 30 of these children who had undergone previous eye examinations at the time of entry to the special school were available but masked to the examiners. The parents or guardians of the remaining 8 children did not recall a previous eye assessment apart from testing by the school nurse or a health visitor. The examinations took place at the special school in a darkened room in an area familiar to the patients. Soft background music was played which had a soothing effect on particularly disruptive children. ${ }^{3}$

The MTI photoscreener (Medical Technology \& Innovations, Inc.) uses a camera with off axis or eccentric photorefraction and fixed flash eccentricity, with respect to the camera lens. A fixed testing distance achieves consistent result.

Photoscreening was carried out initially with both eyes open. If a deviation of the visual axis was detected by the position of the corneal reflexes, each eye was photographed separately to determine the refractive status with accurate fixation (Fig. 1). A twinkling red light, slightly eccentric to the camera flash, was the fixation target. The examiner was at a standard fixed distance as judged by the position of two illuminated red arrows, which were projected onto the patient's forehead and aligned to touch at their points (Fig. 2). Photographs

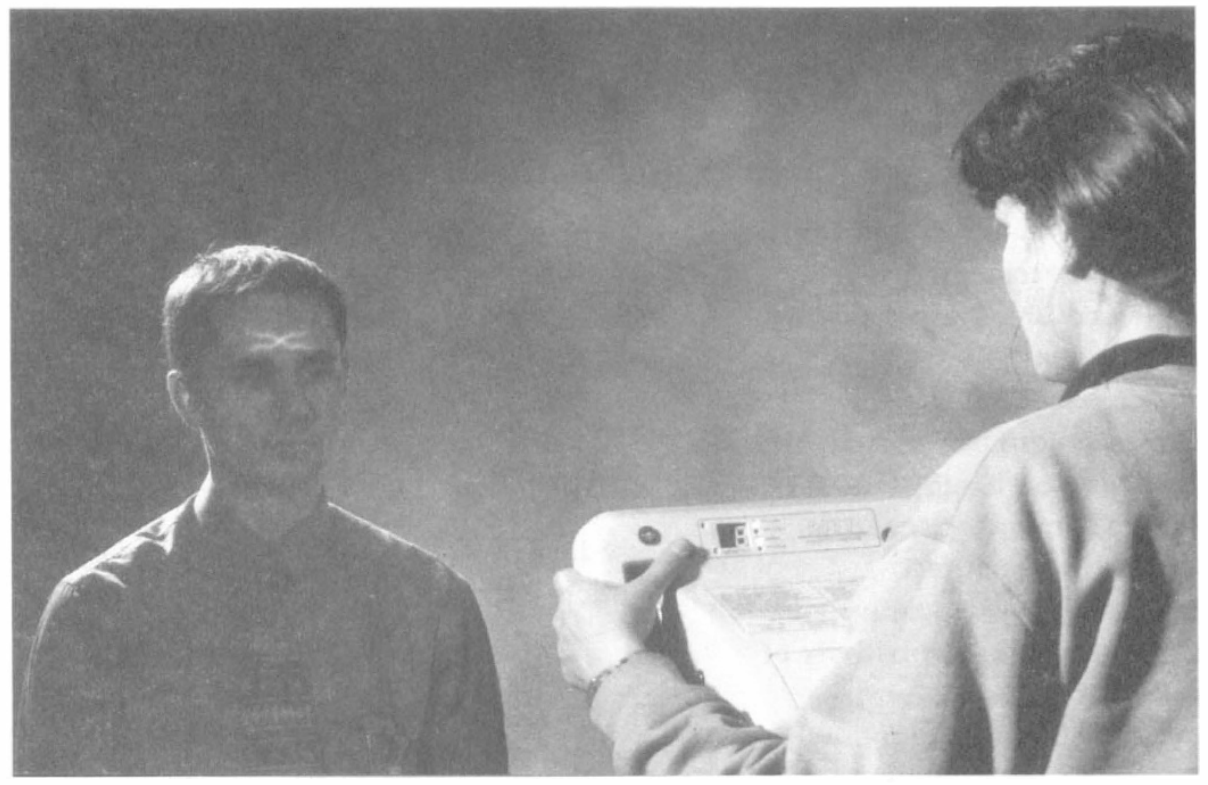

Fig. 2. Demonstration of the use of the photoscreener (in a volunteer), which achieves a constant distance from the examiner to the patient when the illuminated arrowheads meet on the forehead. A twinkling red light and a musical tune, which emanate from the instrument, hold the patient's fixation. 


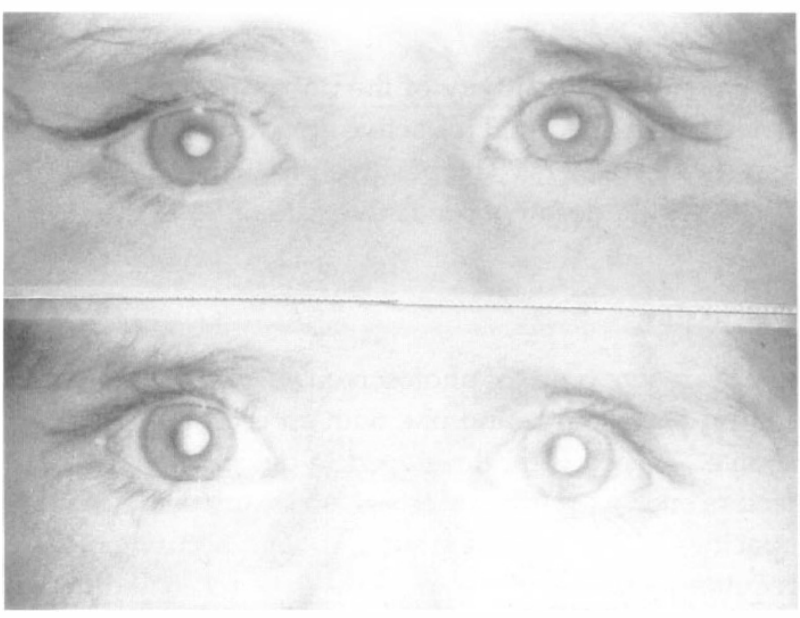

Fig. 3. Case 19. Hypermetropia with astigmatism: the bright cresents are placed inferiorly in the pupillary area in the upper photograph and to the right of the pupillary area in the lower photograph.

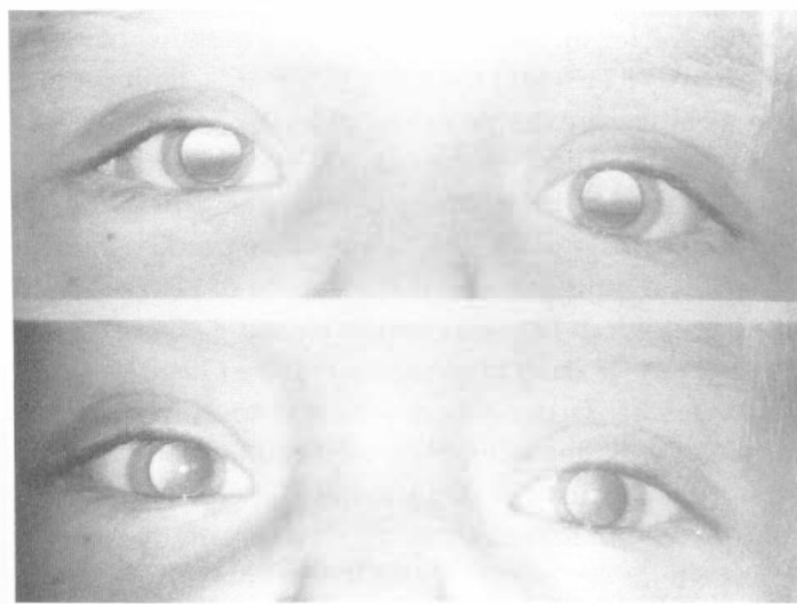

Fig. 4. Case 28. Myopia: the bright cresents are placed superiorly in the pupillary area in the upper photograph and to the left in the pupillary area in the lower photograph.

were repeated if the fixation pattern was inadequate for interpretation. The darkened examination area allowed photoscreening with an ideal pupillary size range of $4 \mathrm{~mm}$ to $8 \mathrm{~mm}$ (mean $6.1 \pm 0.9 \mathrm{~mm}$ ).

The interpretation of the photographs was assessed independently by two examiners (P.W. and K.W.) whose results were masked from each other. The position and the size of the bright crescent provide an estimate of the refractive error. In the upper photograph the flash is oriented horizontally; hence the bright crescents are located either at the top or bottom of the photograph. In the lower photograph the flash is oriented vertically and the bright crescents are formed either to the left or right. The type of refractive error detected for each eye can be interpreted by considering the following:

- An equal-sized bright crescent, $3 \mathrm{~mm}$ or more, located at the bottom in the upper photograph and to the examiner's right in the lower photograph signifies a positive screen for hypermetropia (Fig. 3).

- An equal-sized bright crescent, $2 \mathrm{~mm}$ or more, located at the top in the upper photograph and to the examiner's left in the lower photograph signifies a positive screen for myopia (Fig. 4).

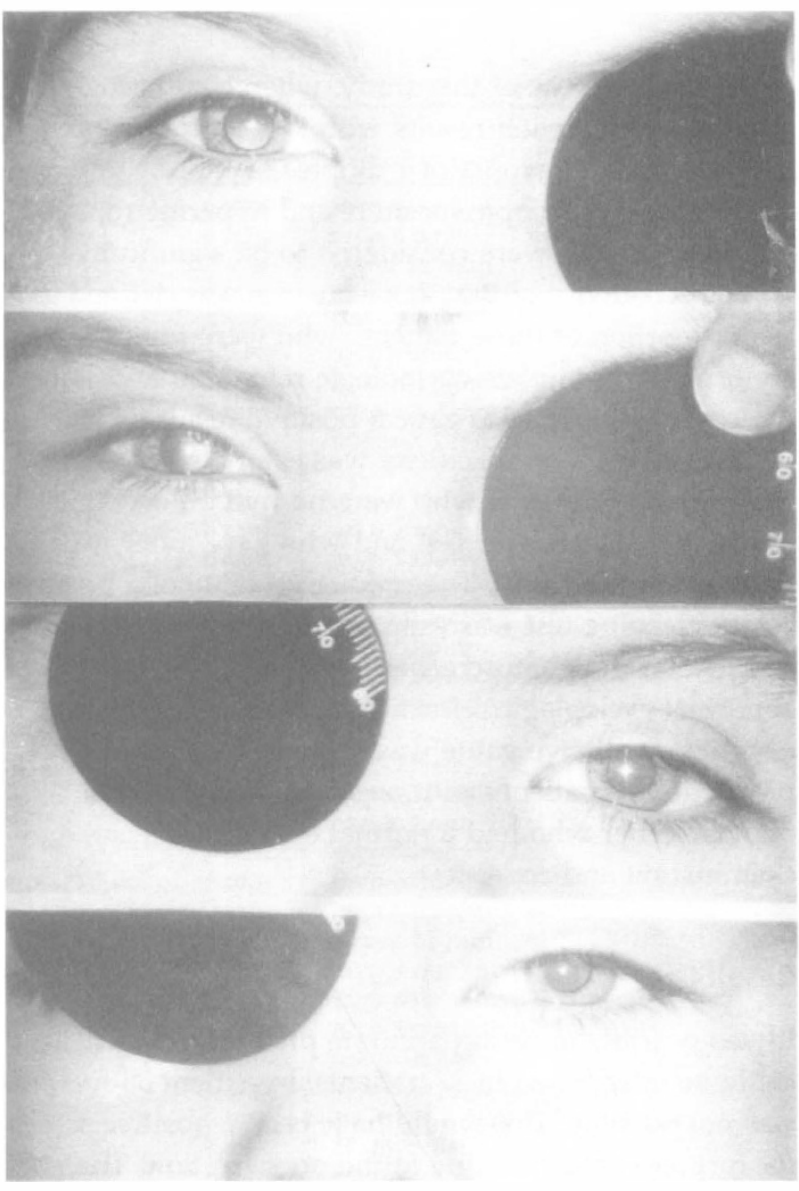

Fig. 5. Case 27. Intermittent right esotropia; photore fraction demonstrates hypermetropia in the right eye and emmetropia in the left (anisometropia). Cycloplegic refraction uncovered hypermetropia in the left eye as well.

- Bright crescents located in the same positions in both eyes, with the same size for the upper and lower photographs but a larger crescent in one eye (difference of $2 \mathrm{~mm}$ or more), signifies anisometropia (Fig. 5).

- A difference of $2 \mathrm{~mm}$ or greater in the size of the bright crescent between the upper and lower photographs of the same eye indicates astigmatism (Fig. 1).

The above interpretations are based on those recommended in the manufacturer's instruction manual for system model MTI-PS100.

In addition to an estimate of the refraction and the presence or absence of strabismus, an evaluation of the lid position and the clarity of the fundal reflex (which is grey) was also possible.

Ophthalmic assessment included a visual acuity assessment if possible with one of the following: Snellen acuity, Sheridan Gardiner test, Kay pictures or Cardiff visual acuity cards. Assessment of the patient's ocular motility and cycloplegic refraction (half an hour after $1 \%$ cyclopentolate was instilled) was then carried out. The media and fundi were examined with a direct and indirect ophthalmoscope. 
For the purpose of this study, when comparing cycloplegic refraction results with the photoscreening positive results, myopia of 1 dioptre or more, astigmatism of 1 dioptre or more and hypermetropia of 2 dioptres or more were considered to be significant.

The sensitivity of the photoscreener was defined as the proportion of those patients who were found to be abnormal on complete cycloplegic refraction and with the cover test who also gave a positive result with the photoscreener. The specificity was estimated as the proportion of patients who were normal on cycloplegic examination and cover test and who gave a negative photoscreening result. The predictive value of a positive photoscreening test was estimated by the proportion positive on the photoscreener and those with an abnormal cycloplegic refraction or cover test. The negative predictive value was estimated as the proportion of patients with negative results on the photoscreener who had a normal cycloplegic examination and cover test.

\section{Results}

It was possible to obtain accurate photographs which could be interpreted in 37 patients. In patient 38 fixation was not possible. This would have been a positive screen for further evaluation due to the poor fixation. The details of patients are included in Table 1.

Although the camera was developed only to estimate the type of refractive error, some quantification of the magnitude of the refractive error based on the size of the bright crescent was possible.

There were 6 patients with manifest esotropia and 4 patients with a manifest exotropia. These patients had additional photographs performed with each eye fixing to evaluate the refractive error of each eye independently with accurate fixation. Agreement was found between the two observers in the interpretation of the photoscreener results in $100 \%$ of cases.

There was a $73.5 \%$ positive screening result with the photorefraction $(65.7 \%$ manifesting refractive errors and $7.8 \%$ with strabismus alone), with 1 false positive refractive error screen and 1 false negative refractive error screen. Of those who screened positive with the MTI photoscreener, $31.5 \%$ (12 patients) had astigmatism, $21.1 \%$ had myopia (8 patients), $13.2 \%$ had hypermetropia (5 patients), $7.8 \%$ had strabismus alone ( 3 patients) and fixation was poor in 1 patient $(2.5 \%)$. The other 7 patients with strabismus screened positive for strabismus and refractive errors.

Cycloplegic refraction revealed that $68.4 \%$ had significant refractive errors with more astigmatism being uncovered, 20 patients had astigmatism, 2 were myopic and 4 were hypermetropic.

The one false positive result was where the photoscreener incorrectly identified myopia. However, the patient had no significant refractive error with cycloplegic refraction. The false negative result was due to the photoscreener failing to identify a significant degree of astigmatism.
The overall sensitivity of the photoscreener in detecting an abnormal refractive error was $92.8 \%$ and the specificity was $90 \%$. The positive predictive rate was $96.4 \%$ with a negative predictive rate of $90 \%$.

\section{Discussion}

There are two types of photoscreeners: one with a coaxial central flash source and one with an eccentric flash source. ${ }^{4-7}$ They were developed to detect amblyogenic factors such as refractive errors, strabismus and media opacities. ${ }^{8,9}$ The coaxial system, though accurate, requires a number of photographs to be taken at different distances and is more complex in its interpretation than the eccentric system. ${ }^{10}$ The MTI photoscreener utilises an eccentric flash source to measure refraction in the vertical and horizontal meridians. The sensitivity of the MTI photorefractor in young children (6-59 months) has been reported as $81.8 \%$ and the specificity $90.6 \%$, with positive and negative predictive values of $68.9 \%$ and $95.2 \%$, respectively. ${ }^{2}$ The Visiscreener 100 , with an eccentric flash source, has been shown to have a sensitivity of $91 \%$ and a specificity of $74 \%$, with a positive predictive value of $84 \%$ and a negative predictive value of $85 \%$, when used in children between 3 months and 8 years. ${ }^{11}$ Two other eccentric flash photoscreeners, the Otago photoscreener (sensitivity of $70 \%$ and specificity of $82 \%$ ) and the Dortmans videophotorefractor (sensitivity of $70 \%$ and specificity of $90 \%$ ), are also useful screening devices for refractive errors. ${ }^{12,13}$ The sensitivity and specificity in our study of children with severe learning disabilities were $92.8 \%$ and $90 \%$, respectively.

In a study by Tong et al. ${ }^{14}$ when preverbal children (aged 3 years or younger) were tested with the MTI photoscreener and the photographs graded by 18 different graders, ranging from paediatric ophthalmologists to Lion's club volunteers, the sensitivities ranged between $37 \%$ and $88 \%$ and specificities between $40 \%$ and $88 \%$. This difference between the results in our study and the one above may be due to the different group of children tested, the graders used (which in our study were an orthoptist and an ophthalmologist) and the number of photograhs taken before an ideal one was chosen for interpretation.

Photoscreening in verbal children and older children of normal intelligence past the amblyogenic age is not necessary due to the relative ease of standard cycloplegic refraction. In non-verbal children with severe learning disabilities, refraction is an arduous task involving a considerable degree of time and patience. Howland and Sayles ${ }^{15}$ found a 4 -fold increase in the prevalence of refractive errors in disabled children compared with normal age-matched children. Neurologically or intellectually impaired children have a higher prevalence of refractive errors. ${ }^{16}$ Mentally handicapped children have a high prevalence of ocular anomalies and 52\% have high refractive errors. ${ }^{17}$ In a Finnish study ${ }^{1}$ of ophthalmic findings in children with severe learning difficulties, the prevalence of refractive errors was inversely related to the level of IQ. In children between 9 
Table 1. Patient details

\begin{tabular}{|c|c|c|c|c|c|c|c|c|c|}
\hline $\begin{array}{l}\text { Case } \\
\text { no. }\end{array}$ & $\begin{array}{c}\text { Age } \\
\text { (years) }\end{array}$ & Sex & Diagnosis & Eye & $\begin{array}{l}\text { Cycloplegic } \\
\text { refraction }\end{array}$ & $\begin{array}{l}\text { Ocular } \\
\text { examination }\end{array}$ & $\begin{array}{l}\text { Pupil } \\
\text { size }\end{array}$ & Photo-crescent & $\begin{array}{l}\text { No. of } \\
\text { photographs }\end{array}$ \\
\hline 1 & 6 & $\mathrm{M}$ & $\mathrm{cp} /$ nystagmus & $\begin{array}{l}\mathrm{R} \\
\mathrm{L}\end{array}$ & $\begin{array}{l}-9.00 /-3.00 \times 180 \\
-9.00 /-3.00 \times 180\end{array}$ & nystagmus & $\begin{array}{l}6 \mathrm{~mm} \\
6 \mathrm{~mm}\end{array}$ & $\begin{array}{l}\text { myp } 4 \mathrm{~mm} \\
\operatorname{myp} 4 \mathrm{~mm}\end{array}$ & 2 \\
\hline 2 & 9 & $\mathrm{M}$ & sld/bp & $\begin{array}{l}\mathrm{R} \\
\mathrm{L}\end{array}$ & $\begin{array}{l}+7.50 \\
+7.50\end{array}$ & - & $\begin{array}{l}7 \mathrm{~mm} \\
7 \mathrm{~mm}\end{array}$ & $\begin{array}{l}\text { hyper } 6.5 \mathrm{~mm} \\
\text { hyper } 6.5 \mathrm{~mm}\end{array}$ & 1 \\
\hline 3 & 14 & $\mathrm{M}$ & sld/bp & $\begin{array}{l}\mathrm{R} \\
\mathrm{L}\end{array}$ & $\begin{array}{l}-0.50 \\
-0.50\end{array}$ & - & $\begin{array}{l}5.5 \mathrm{~mm} \\
5.5 \mathrm{~mm}\end{array}$ & $\begin{array}{l}\text { myp } 1 \mathrm{~mm} \\
\operatorname{myp} 1 \mathrm{~mm}\end{array}$ & 1 \\
\hline 4 & 11 & $\mathrm{M}$ & sld/nai & $\begin{array}{l}\mathrm{R} \\
\mathrm{L}\end{array}$ & $\begin{array}{l}-1.50 \\
-1.50\end{array}$ & - & $\begin{array}{l}7 \mathrm{~mm} \\
7 \mathrm{~mm}\end{array}$ & $\begin{array}{l}\text { myp ast } 3 \mathrm{~mm} / 1 \mathrm{~mm} \\
\text { myp ast } 3 \mathrm{~mm} / 1 \mathrm{~mm}\end{array}$ & 1 \\
\hline 5 & 6 & $\mathrm{M}$ & $\begin{array}{l}\text { sld/aut } \\
\text { bp }\end{array}$ & $\begin{array}{l}\mathrm{R} \\
\mathrm{L}\end{array}$ & $\begin{array}{l}+0.75 \\
+0.75\end{array}$ & - & $\begin{array}{l}5 \mathrm{~mm} \\
5 \mathrm{~mm}\end{array}$ & $\begin{array}{l}\text { hyper }<1 \mathrm{~mm} \\
\text { hyper }<1 \mathrm{~mm}\end{array}$ & 2 \\
\hline 6 & 17 & $\mathrm{M}$ & $\begin{array}{l}\text { RTA/brain } \\
\text { damage }\end{array}$ & $\begin{array}{l}\mathrm{R} \\
\mathrm{L}\end{array}$ & $\begin{array}{l}+0.50 \\
+0.25\end{array}$ & $\begin{array}{l}\text { pale disc } \\
\text { pale disc }\end{array}$ & $\begin{array}{l}7 \mathrm{~mm} \\
8 \mathrm{~mm}\end{array}$ & $\begin{array}{l}\text { myp } 1 \mathrm{~mm} \\
\text { myp } 1 \mathrm{~mm}\end{array}$ & 3 \\
\hline 7 & 14 & $\mathrm{~F}$ & $\begin{array}{l}\text { sld } / \text { bp } \\
\text { epilepsy }\end{array}$ & $\begin{array}{l}\mathrm{R} \\
\mathrm{L}\end{array}$ & $\begin{array}{l}\text { emmetropic } \\
-0.5 \text { at } 180\end{array}$ & $\begin{array}{l}- \\
-\end{array}$ & $\begin{array}{l}6 \mathrm{~mm} \\
5 \mathrm{~mm}\end{array}$ & $\begin{array}{l}\text { myp } 1 \mathrm{~mm} \\
\text { myp } 1 \mathrm{~mm}\end{array}$ & 1 \\
\hline 8 & 11 & M & $\begin{array}{l}\text { sld } \\
\text { labands }\end{array}$ & $\begin{array}{l}\mathrm{R} \\
\mathrm{L}\end{array}$ & $\begin{array}{l}+1.00 \\
+1.00\end{array}$ & - & $\begin{array}{l}7 \mathrm{~mm} \\
7 \mathrm{~mm}\end{array}$ & $\begin{array}{l}\text { hyper } 1.5 \mathrm{~mm} \\
\text { hyper } 1 \mathrm{~mm}\end{array}$ & 2 \\
\hline 9 & 18 & $\mathrm{~F}$ & $\begin{array}{l}\text { sld } \\
\text { epilepsy }\end{array}$ & $\begin{array}{l}\mathrm{R} \\
\mathrm{L}\end{array}$ & $\begin{array}{l}-0.75 /+2 \times 90 \\
-0.75 /+2.00 \times 90\end{array}$ & $\begin{array}{l}- \\
-\end{array}$ & $\begin{array}{l}7 \mathrm{~mm} \\
7 \mathrm{~mm}\end{array}$ & $\begin{array}{l}\text { myp } 2 \mathrm{~mm} / \mathrm{hyp} 1 \mathrm{~mm} \\
\mathrm{myp} 2 \mathrm{~mm} / \mathrm{hyp} 1 \mathrm{~mm}\end{array}$ & 2 \\
\hline 10 & 12 & $\mathrm{~F}$ & $\begin{array}{l}\text { sld } / 21 \\
\text { spina bifida }\end{array}$ & $\begin{array}{l}\mathrm{R} \\
\mathrm{L}\end{array}$ & $\begin{array}{l}-0.75 /+2.50 \times 40 \\
-4.00 /+5.00 \times 120\end{array}$ & (L)ET-15 & $\begin{array}{l}6 \mathrm{~mm} \\
6 \mathrm{~mm}\end{array}$ & $\begin{array}{l}\text { myp } 1 \mathrm{~mm} \\
\text { myp } 1 \mathrm{~mm}\end{array}$ & 2 \\
\hline 11 & 16 & $\mathrm{~F}$ & $\begin{array}{l}\text { cp } \\
\text { epilepsy }\end{array}$ & $\begin{array}{l}\mathrm{R} \\
\mathrm{L}\end{array}$ & $\begin{array}{l}+6.00 \\
+7.50 / 1.50 \times 90\end{array}$ & - & $\begin{array}{l}5 \mathrm{~mm} \\
5 \mathrm{~mm}\end{array}$ & $\begin{array}{l}\text { hyper } 3.5 \mathrm{~mm} \\
\text { hyper } 4 \mathrm{~mm}\end{array}$ & 2 \\
\hline 12 & 17 & $\mathrm{~F}$ & sld & $\begin{array}{l}\mathrm{R} \\
\mathrm{L}\end{array}$ & $\begin{array}{l}-16.00 \\
-12.00 /-4.00 \times 60\end{array}$ & & $\begin{array}{l}6 \mathrm{~mm} \\
6 \mathrm{~mm}\end{array}$ & $\begin{array}{l}\text { myp } 5 \mathrm{~mm} \\
\text { myp } 5 \mathrm{~mm}\end{array}$ & 3 \\
\hline 13 & 12 & $\mathrm{~F}$ & $\begin{array}{l}\text { sld } / \text { bp } \\
\text { epilepsy }\end{array}$ & $\begin{array}{l}\mathrm{R} \\
\mathrm{L}\end{array}$ & $\begin{array}{l}+4.50 \\
+3.00 /+1.00 \times 110\end{array}$ & ptosis & $\begin{array}{l}7 \mathrm{~mm} \\
7 \mathrm{~mm}\end{array}$ & $\begin{array}{l}\text { hyper } 4.5 \mathrm{~mm} \\
\text { hyper } 4.5 \mathrm{~mm}\end{array}$ & 2 \\
\hline 14 & 15 & $\mathrm{M}$ & sld & $\begin{array}{l}\mathrm{R} \\
\mathrm{L}\end{array}$ & $\begin{array}{l}-1.25 /-1.50 \times 180 \\
-1.25 /-2.25 \times 180\end{array}$ & (R)XT-20 & $\begin{array}{l}7 \mathrm{~mm} \\
7 \mathrm{~mm}\end{array}$ & $\begin{array}{l}\text { myp } 4 \mathrm{~mm} / \text { myp } 1 \mathrm{~mm} \\
\text { myp } 4 \mathrm{~mm} / \mathrm{myp} 2 \mathrm{~mm}\end{array}$ & 4 \\
\hline 15 & 13 & $\mathrm{~F}$ & sld & $\begin{array}{l}\mathrm{R} \\
\mathrm{L}\end{array}$ & $\begin{array}{l}-2.00 /-5 \times 180 \\
-3.00 /-4 \times 180\end{array}$ & (L)XT-10 & $\begin{array}{l}6.5 \mathrm{~mm} \\
6.5 \mathrm{~mm}\end{array}$ & $\begin{array}{l}\text { myp } 4 \mathrm{~mm} / \text { myp } 3 \mathrm{~mm} \\
\text { not possible }\end{array}$ & 2 \\
\hline 16 & 15 & $\mathrm{~F}$ & $\begin{array}{l}\text { sld/Down's } \\
\text { syndrome }\end{array}$ & $\begin{array}{l}\mathrm{R} \\
\mathrm{L}\end{array}$ & $\begin{array}{l}-1.00 /+2.75 \times 90 \\
+0.5 /+2.00 \times 90\end{array}$ & (R)ET-18 & $\begin{array}{l}6 \mathrm{~mm} \\
6 \mathrm{~mm}\end{array}$ & $\begin{array}{l}\text { ast-nil/hyper } 4 \mathrm{~mm} \\
\text { ast hyper } 1 \mathrm{~mm} / \text { hyper } 3 \mathrm{~mm}\end{array}$ & m \\
\hline 17 & 15 & $\mathrm{~F}$ & sld/bp & $\begin{array}{l}\mathrm{R} \\
\mathrm{L}\end{array}$ & $\begin{array}{l}-1.00 /-6.50 \times 160 \\
-1.25 /-4.25 \times 180\end{array}$ & (R)XT-20 & $\begin{array}{l}8 \mathrm{~mm} \\
8 \mathrm{~mm}\end{array}$ & $\begin{array}{l}\text { ast myp } 6 \mathrm{~mm} / \mathrm{myp} 3 \mathrm{~m} \\
\text { ast myp } 6 \mathrm{~mm} / 7 \mathrm{~mm}\end{array}$ & 4 \\
\hline 18 & 6 & M & $\begin{array}{l}\mathrm{cp} / \mathrm{sld} \\
\text { deaf }\end{array}$ & $\begin{array}{l}\mathrm{R} \\
\mathrm{L}\end{array}$ & $\begin{array}{l}-1.75 /+2.25 \times 90 \\
-1.75 /+2.75 \times 90\end{array}$ & nystagmus & $\begin{array}{l}4 \mathrm{~mm} \\
4 \mathrm{~mm}\end{array}$ & $\begin{array}{l}\text { emm } \\
\text { ast-nil/hyper } 2 \mathrm{~mm}\end{array}$ & 2 \\
\hline 19 & 9 & M & sld & $\begin{array}{l}\mathrm{R} \\
\mathrm{L}\end{array}$ & $\begin{array}{l}+5.00 /+5.00 \times 90 \\
+6.00 /+2.00 \times 90\end{array}$ & $\begin{array}{l}\text { onh } \\
-\end{array}$ & $\begin{array}{l}4 \mathrm{~mm} \\
4 \mathrm{~mm}\end{array}$ & $\begin{array}{l}\text { ast hyper } 2.5 \mathrm{~mm} / 3.5 \mathrm{~mm} \\
\text { ast hyper } 2.5 \mathrm{~mm} / 3.5 \mathrm{~mm}\end{array}$ & 2 \\
\hline 20 & 15 & $\mathrm{~F}$ & $\begin{array}{l}22 \text { deletion } \\
\text { sld, epilepsy/cp }\end{array}$ & $\begin{array}{l}\mathrm{R} \\
\mathrm{L}\end{array}$ & $\begin{array}{l}-6.00 \\
-5.50 /-1.00 \times 180\end{array}$ & - & $\begin{array}{l}7 \mathrm{~mm} \\
7 \mathrm{~mm}\end{array}$ & $\begin{array}{l}\text { myp } 6 \mathrm{~mm} \\
\text { myp } 6 \mathrm{~mm}\end{array}$ & 1 \\
\hline 21 & 15 & $\mathrm{~F}$ & $\begin{array}{l}\text { sld } \\
\text { epilepsy }\end{array}$ & $\begin{array}{l}\mathrm{R} \\
\mathrm{L}\end{array}$ & $\begin{array}{l}+0.50 \\
+0.50 /+0.50\end{array}$ & (L)XT-10 & $\begin{array}{l}6 \mathrm{~mm} \\
6 \mathrm{~mm}\end{array}$ & $\begin{array}{l}\text { myp } 1.5 \mathrm{~mm} \\
\text { emm }\end{array}$ & 4 \\
\hline 22 & 9 & $\mathrm{M}$ & $\begin{array}{l}\text { cp/epilepsy } \\
\text { diplegia }\end{array}$ & $\begin{array}{l}\mathrm{R} \\
\mathrm{L}\end{array}$ & $\begin{array}{l}\text { emmetropic } \\
\text { emmetropic }\end{array}$ & - & $\begin{array}{l}6 \mathrm{~mm} \\
6 \mathrm{~mm}\end{array}$ & $\begin{array}{l}\mathrm{emm} \\
\mathrm{emm}\end{array}$ & 2 \\
\hline 23 & 6 & $\mathrm{~F}$ & $\begin{array}{l}\mathrm{cp} / \text { quad riparesis } \\
\text { sld/premature }\end{array}$ & $\begin{array}{l}\mathrm{R} \\
\mathrm{L}\end{array}$ & $\begin{array}{l}-0.5 \\
\text { emmetropic }\end{array}$ & $\begin{array}{l}\text { disc col } \\
\text { (R)ET-20 }\end{array}$ & $\begin{array}{l}5 \mathrm{~mm} \\
5 \mathrm{~mm}\end{array}$ & $\begin{array}{l}\text { myp } 3 \mathrm{~mm} \\
\text { emm }\end{array}$ & 2 \\
\hline 24 & 4 & M & $\begin{array}{l}\text { sld } \\
\text { cp-athetoid }\end{array}$ & $\begin{array}{l}\mathrm{R} \\
\mathrm{L}\end{array}$ & $\begin{array}{l}+0.5 \\
+0.5\end{array}$ & - & $\begin{array}{l}6 \mathrm{~mm} \\
6 \mathrm{~mm}\end{array}$ & $\begin{array}{l}\text { myp } 2 \mathrm{~mm} \\
\text { myp } 2 \mathrm{~mm}\end{array}$ & 2 \\
\hline 25 & 3 & $\mathrm{~F}$ & $\begin{array}{l}\text { cp } \\
\text { n. convulsions }\end{array}$ & $\begin{array}{l}\mathrm{R} \\
\mathrm{L}\end{array}$ & $\begin{array}{l}+1.25 / 0.75 \times 90 \\
+1.75 /+1.25 \times 90\end{array}$ & - & $\begin{array}{l}7 \mathrm{~mm} \\
7 \mathrm{~mm}\end{array}$ & $\begin{array}{l}\text { hyper } 6 \mathrm{~mm} \\
\text { hyper } 6 \mathrm{~mm}\end{array}$ & 2 \\
\hline 26 & 6 & $\mathrm{~F}$ & $\begin{array}{l}\text { sld/aut } \\
\text { bp }\end{array}$ & $\begin{array}{l}\mathrm{R} \\
\mathrm{L}\end{array}$ & $\begin{array}{l}0 /+1.25 \times 90 \\
0 /-1.25 \times 180\end{array}$ & - & $\begin{array}{l}6 \mathrm{~mm} \\
6 \mathrm{~mm}\end{array}$ & $\begin{array}{l}\text { ast-nil } / 2 \mathrm{~mm} \text { hyper } \\
\text { emm }\end{array}$ & 2 \\
\hline 27 & 4 & $\mathrm{~F}$ & sld/dd & $\begin{array}{l}\mathrm{R} \\
\mathrm{L}\end{array}$ & $\begin{array}{l}+3.50 \\
+3.75\end{array}$ & (R)ET -14 & $\begin{array}{l}6 \mathrm{~mm} \\
6 \mathrm{~mm}\end{array}$ & $\begin{array}{l}\text { hyper } 3 \mathrm{~mm} \\
\text { hyper } 1 \mathrm{~mm}\end{array}$ & 4 \\
\hline 28 & 4 & $\mathrm{~F}$ & sld/dd & $\begin{array}{l}\mathrm{R} \\
\mathrm{L}\end{array}$ & $\begin{array}{l}-1.75 /-1.25 \times 180 \\
-2.00 /-1.50 \times 180\end{array}$ & - & $\begin{array}{l}7 \mathrm{~mm} \\
7 \mathrm{~mm}\end{array}$ & $\begin{array}{l}\text { myp } 4 \mathrm{~mm} \\
\text { myp } 4 \mathrm{~mm}\end{array}$ & 1 \\
\hline 29 & 7 & $\mathrm{~F}$ & sld & $\begin{array}{l}\mathrm{R} \\
\mathrm{L}\end{array}$ & $\begin{array}{l}+1.00 \\
+0.75 /+1.00 \times 140\end{array}$ & $\begin{array}{l}\text { (R)ET-12 } \\
\text { (L)HT }\end{array}$ & $\begin{array}{l}6 \mathrm{~mm} \\
6 \mathrm{~mm}\end{array}$ & $\begin{array}{l}\text { ast-hyper } 3 \mathrm{~mm} / 1 \mathrm{~mm} \\
\text { hyper } 3 \mathrm{~mm}\end{array}$ & 2 \\
\hline 30 & 6 & $\mathrm{~F}$ & add/sld & $\begin{array}{l}\mathrm{R} \\
\mathrm{L}\end{array}$ & $\begin{array}{l}+1.00 \\
+1.00\end{array}$ & & $\begin{array}{l}6 \mathrm{~mm} \\
6 \mathrm{~mm}\end{array}$ & $\begin{array}{l}\text { myp } 1 \mathrm{~mm} \\
\text { myp } 1 \mathrm{~mm}\end{array}$ & 2 \\
\hline 31 & 8 & $\mathrm{~F}$ & $\begin{array}{l}\text { gdd/sld } \\
\text { bp }\end{array}$ & $\mathrm{R}$ & $\begin{array}{l}+1.75 \\
+2.75\end{array}$ & (R)ET & $\begin{array}{l}5.5 \mathrm{~mm} \\
5.5 \mathrm{~mm}\end{array}$ & $\begin{array}{l}\text { emm } \\
\text { emm }\end{array}$ & 2 \\
\hline 32 & 7 & M & $\begin{array}{l}\text { sld } \\
\text { deaf-sn }\end{array}$ & $\begin{array}{l}\mathrm{R} \\
\mathrm{L}\end{array}$ & $\begin{array}{l}+1.00 /+3.00 \times 90 \\
+1.00 /+3.00 \times 90\end{array}$ & - & $\begin{array}{l}6 \mathrm{~mm} \\
6 \mathrm{~mm}\end{array}$ & $\begin{array}{l}\text { ast-hyper }<1 \mathrm{~mm} / 3 \mathrm{~mm} \\
\text { ast-hyper } 1 \mathrm{~mm} / 3 \mathrm{~mm}\end{array}$ & 1 \\
\hline 33 & 4 & M & deaf/sld & $\begin{array}{l}\mathrm{R} \\
\mathrm{L}\end{array}$ & $\begin{array}{l}+2.00 \\
+2.00\end{array}$ & - & $\begin{array}{l}6 \mathrm{~mm} \\
6 \mathrm{~mm}\end{array}$ & $\begin{array}{l}\text { ast-hyper }<1 \mathrm{~mm} / 2 \mathrm{~mm} \\
\text { ast-hyper }<1 \mathrm{~mm} / 2 \mathrm{~mm}\end{array}$ & 1 \\
\hline 34 & 6 & M & $\begin{array}{l}\text { gdd/cp } \\
\text { dyspraxia }\end{array}$ & $\begin{array}{l}\mathrm{R} \\
\mathrm{L}\end{array}$ & $\begin{array}{l}+0.75 \\
+0.75\end{array}$ & - & $\begin{array}{l}6 \mathrm{~mm} \\
6 \mathrm{~mm}\end{array}$ & $\begin{array}{l}\text { hyper } 1 \mathrm{~mm} \\
\text { hyper } 1 \mathrm{~mm}\end{array}$ & 2 \\
\hline 35 & 4 & M & sld/ & $\begin{array}{l}\mathrm{R} \\
\mathrm{L}\end{array}$ & $\begin{array}{l}-0 /+1.25 \times 90 \\
-0 / 1+1.00 \times 90\end{array}$ & & $\begin{array}{l}6 \mathrm{~mm} \\
6 \mathrm{~mm}\end{array}$ & $\begin{array}{l}\text { ast-hyper nil/1 } \mathrm{mm} \\
\text { ast hyper nil/1 mm }\end{array}$ & 1 \\
\hline 36 & 4 & $\mathrm{M}$ & sld/dd & $\mathrm{R}$ & $\begin{array}{l}0 /+0.50 \times 90 \\
0 /+0.50 \times 90\end{array}$ & - & $\begin{array}{l}6 \mathrm{~mm} \\
6 \mathrm{~mm}\end{array}$ & $\begin{array}{l}\text { emm } \\
\text { emm }\end{array}$ & 2 \\
\hline 37 & 18 & $\mathrm{~F}$ & $\begin{array}{l}\mathrm{cp} \\
\text { hypertension }\end{array}$ & $\begin{array}{l}\mathrm{R} \\
\mathrm{L}\end{array}$ & $\begin{array}{l}-2.75 \\
-2.25\end{array}$ & (L) RD & $\begin{array}{l}6 \mathrm{~mm} \\
6 \mathrm{~mm}\end{array}$ & $\begin{array}{l}\text { myp } 3 \mathrm{~mm} \\
\text { myp } 2 \mathrm{~mm}\end{array}$ & 3 \\
\hline 38 & 15 & $\mathrm{~F}$ & $\begin{array}{l}\text { cri du chat syndrome } \\
\text { sld }\end{array}$ & $\begin{array}{l}\mathrm{R} \\
\mathrm{L}\end{array}$ & $\begin{array}{l}+1.50 / 2.50 \times 145 \\
+1.00 /+1.00 \times 90 \\
\end{array}$ & & $\begin{array}{l}6 \mathrm{~mm} \\
6 \mathrm{~mm} \\
\end{array}$ & $\begin{array}{l}\text { no fixation } \\
\text { no fixation }\end{array}$ & 4 \\
\hline
\end{tabular}

$\mathrm{M}$, male; F, female; sld, severe learning disabilities; dd, developmental delay; bp, behaviour problems; cp, cerebral palsy; gdd, global developmental delay; sn, sensory neural; aut, autism; onh, optic nerve hypoplasia; disc col, disc coloboma, nai, non-accidental injury; RTA, road traffic accident; L, left; R, right; emm, emmetropia; hyper, hypermetropia; myp, myopia; ast, astigmatism; RD, retinal detachment; ET, esotropia; XT, exotropia. 
and 10 years, with an IQ of less than 50, only $21-25 \%$ were emmetropic. In school children with cerebral palsy significant refractive errors were found in $50 \%$ and strabismus amblyopia in $15 \% .{ }^{18}$

All children with severe learning disabilities hence need ocular assessment to rule out ocular defects and refractive errors. A method of screening these patients for significant refractive errors would allow targeting of limited resources and a better utilisation of time. The use of a photoscreener to detect refractive errors, in this specific group of patients, had not previously been described. This study shows that it is a useful accessory when evaluating the ocular status of such children.

The percentage of children in this group with abnormal screening results with the MTI photoscreener was $65.7 \%$ for refractive errors, with an additional $7.8 \%$ with strabismus alone, which is similar to other studies reporting refractive errors in similar children.

Though screening is best performed before the age where irreversible amblyopia sets in, the photoscreener may also be used to screen children on a regular followup basis to detect developmental myopia. The use of the new hand-held autorefractor might also prove to be a useful tool for evaluation of refractive errors in this group of children. ${ }^{19}$

\section{Conclusions}

It is possible to photorefract children with severe learning disabilities accurately. Photoscreening may be used as a method of detecting significant refractive errors and strabismus in this group of children and allows targeting of further evaluation of those screening positive. The portable MTI photoscreener could easily be used effectively by any trained health worker in special schools to detect significant refractive errors that may be referred for further specialist evaluation.

\section{References}

1. Tuppurainen $\mathrm{K}$. Ocular findings among mentally retarded children in Finland. Acta Ophthalmol (Copenh) 1983;61:634-44.

2. Ottar WL, Scott WE, Holgado SI. Photoscreening for amblyogenic factors. J Pediatr Ophthalmol Strabismus 1995;32:289-95.
3. Oldfield A, Adams M. The effects of music therapy on a group of profoundly mentally handicapped adults. J Ment Defic Res 1990;34:107-25.

4. Howland HC, Braddick O, Atkinson J, Howland B. Optics of photorefraction: orthogonal and isotropic methods. J Opt Soc Am 1983;73:1701-8.

5. Hamer RD, Norcia AM, Day SH, Haegerstrom-Portnoy G, Lewis D, Hsu-Winges C. Comparison of on- and off-axis photorefraction with cycloplegic retinoscopy in infants. J Pediatr Ophthalmol Strabismus 1992;29:232-9.

6. Bobier WR, Braddick OJ. Eccentric photorefraction: optical analysis and empirical measures. Am J Optom Physiol Optics 1985;62:614-20.

7. Wesemann W, Norcia AM, Allen D. Theory of eccentric photorefraction (photoretinoscopy): astigmatic eyes. J Opt Soc AM 1991;8:2038-47.

8. Atkinson J, Braddick O, Bobier B, Anker S, Ehrlich D, King J, et al. Two infant vision screening programmes: prediction and prevention of strabismus and amblyopia from photoand videorefractive screening. Eye 1996;10:189-98.

9. Morgan KS, Kennemer JC. Off-axis photorefractive eye screening in children. J Cataract Refract Surg 1997;23:423-8.

10. Atkinson J, Braddick OJ, Durden K, Watson PG, Atkinson S. Screening for refractive errors in 6-9 month old infants by photorefraction. Br J Ophthalmol 1984;68:105-12.

11. Morgan KS, Johnson WD. Clinical evaluation of a commercial photorefractor. Arch Ophthalmol 1987;105:1528-31.

12. Cooper CD, Bowling FG, Hall JE, Colville DJ, Dortmans RJ, Munch J, et al. Evaluation of photoscreener instruments in a childhood population. 1. Otago. Aust NZ J Ophthalmol 1996;24:347-55.

13. Kennedy RA, Sheps SB. A comparison of photoscreening techniques for amblyogenic factors in children. Can J Ophthalmol 1989;24:259-64.

14. Tong PY, Enke-Miyazaki E, Bassin RE, Tielsch JM, Stager DR, Beauchamp GR, et al. The National Children's Eye Care Foundation Vision Screening Study Group. Screening for amblyopia in preverbal children. Ophthalmology 1998;105:856-63.

15. Howland HC, Sayles N. Photorefractive studies of normal and handicapped infants and children. Behav Brain Res. 1983;10:81-5.

16. Mackie RT, McCulloch DL, Saunders KJ, Day RE, Phillips S, Dutton GN. Relation between neurological status, refractive error, and visual acuity in children: a clinical study. Dev Med Child Neurol 1998;40:31-7.

17. Kennerley Bankes JL. Eye defects in mentally handicapped children. BMJ 1974;II:533-5.

18. Black P. Visual disorders associated with cerebral palsy. Br J Ophthalmol 1982;66:46-52.

19. Harvey EM, Miller JM, Wagner LK, Dobson V. Reproducibility and accuracy of measurements with a hand held autorefractor in children. Br J Ophthalmol 1997;81:941-8. 